\title{
The Use of Public Polls, Surveys and Sampling as Evidence in Litigation, and Particularly Trademark and Unfair Competition Casest
}

\author{
Reginald E. Caughey*
}

The basic issue in trademark infringement actions by virtue of the provisions of section 32 of the Lanham Act of 1946 is actual confusion, or likelihood of confusion, as to the source or origin of the goods or services in question.

The Supreme Court of the United States in Hanover Star Milling Co. v. Metcalf, in discussing trademark infringement and unfair conpetition, stated: ${ }^{2}$

The essence of the wrong consists in the sale of the goods of one manufacturer or vendor for those of another....

This essential element is the same in trade-mark cases as in cases of unfair competition unaccompanied with trade-mark infringement.

For all practical purposes, therefore, and particularly for the subject here discussed, we nuay consider that the basic issue in unfair competition cases is the same as in actions for trademark infringenent under the Lanham Act.

The use of witnesses to prove actual confusion is, of course, preferred. However, in many instances it is extremely difficult to produce such proof. The confused purchaser may in fact never become aware of his mistake. If he does become aware of the same, in the large majority of instances this information does not come to the attention of the plaintiff in an action for infringement. If found, the confused purchaser frequently refuses to admit the mistake or to testify as to it. Furthermore, plaintiffs have frequently found it inadvisable to put sufficient pressure upon prospective witnesses to cause them to testify as to confusion. The various difficulties encountered in securing evidence of actual confusion and thereafter proving the same

$\dagger$ The writer has had the privilege in writing this article to have had access to an unpublished report of Hiram C. Barksdale entitled "On the Use of Sample Survey Data as Evidence in Legal Proceedings." This report is exhaustive and instructive and was prepared by Mr. Barksdale in partial fulfillment of the requirements for his degree of Doctor of Philosophy in Business Administration from New York University. This report has been very helpful and although not yet in print it is hoped it will be printed so it will be available to those who are interested.

* Member, Los Angeles Bar.

1240 U.S. 403 (1916).

2 Id. at 413. 
have caused those seeking to prove confusion to endeavor to find other methods of doing so.

The attorney for the claimant in trademark actions was frequently one who practiced patent law. The use of expert witnesses in patent cases undoubtedly led to their use in attempting to prove likelihood of confusion. The Supreme Court in McLean v Fleming ${ }^{3}$ stated that the test of likelihood of confusion was the misleading or deception of the ordinary purchaser. This view together with the rejection of the use of expert testimony to prove confusion in the case of Gorham Co. v. White ${ }^{4}$ led the attorneys to seek other methods.

In $1880^{5}$ resort was made to the use of primted forms of affidavits which were sent throughout the Umited States, executed and offered in evidence in a trademark infrigement action upon the issue of confusion. The court in its opinion frowned upon this method, stating: ${ }^{6}$

[T] he method pursued in obtaming this testimony, generally, does not recommend it to our confidence... This method of obtaining testimony is not worthy of encouragement.

The late Edward S. Rogers of Chicago, probably in his time the foremost trademark attorney in the United States, early in this century recognized the deficiency in methods used to establish proof of confusion in trademark infringement actions. ${ }^{7}$ He used a psychological approach and followed the suggestions of Hugo Münsterberg, Professor of Psychology at Harvard University. Although such tests were admitted in evidence in Coca-Cola Co. v. Chero-Cola Co., ${ }^{9}$ neither the Commissioner of Patents nor the Court of Appeals of the District of Columbia gave any weight to then.

In Citizens' Wholesale Supply Co. v. Downing ${ }^{10}$ similar psychological tests were presented to measure the degree of confusion between two trade names. The court in deciding the case did not discuss the competency of the evidence. As late as 1942 in C. B. Shane Corp. v. Ellis Coat Co. ${ }^{11}$ the same approach was used before the Commissioner of Patents on the question of

396 U.S. 245 (1878).

481 U.S. (14 Wall.) 511 (1871) (a design patent case where the test of infringement is substantially the same as in a trademark infringement action).

5 Carroll v. Ertheher, 1 Fed. 688 (C.C.E.D.Pa. 1880).

6 Id. at 690 .

7 Rogers, The Unwary Purchaser: A Study in the Psychology of Trademark Infringement, 8 MTCH. L. REv. 613 (1910).

8 Münsterberg, Psychology and the Market, 34 McClure's Magazine, Nov. 1909, pp. 87-93. This article was subsequently published as chapter seven, Münsterberg, AMERICAN PrGbieMrs FROM THE POINT OF VIEW OF A PSYCHOLOGIST (1910).

9273 Fed. 755 (D.C. Cir. 1921).

10107 Ohio St. 422,140 N.E. 683 (1923).

1153 U.S.P.Q. 525 (Comm'r 1942). 
likelihood of confusion. The Commissioner again rejected the results of the psychological tests, stating that he considered the same wholly inconclusive and of no probative force and to be incompetent as evidence of confusing similarity of the marks. This particular method has failed to gain support as a means of proving likelihood of confusion and little or no use of the same has been made, particularly in trademark infringement actions, during recent years.

The use of investigators to secure evidence of likelihood of confusion was another method used where witnesses were not available to prove actual confusion. The investigators were usually paid by the party who presented the evidence to the court, and as a result not much credence or weight was given to the testimony or to the evidence presented. The method of determining by surveys whether the accused mark is likely to deceive by interviewing or otherwise contacting a portion of the purchasing public has gradually within the past few years been recognized as the best possible evidence. By contacting a cross-section of the purchasing public, the reactions secured as to the likelihood of confusion were, in a properly conducted survey, the same type of reaction which the Supreme Court of the Umited States approved as a test of infringement in McLean $v$ Fleming, ${ }^{12} i . e$. , the reaction of the ordimary purchaser.

Where the reaction of the ordinary purchaser is to be proved not by actual confusion in purchasing through the ordinary channels of trade but by questions directed to the ordinary person to secure his reaction as to likelihood of confusion, then the legal question arises as to the admissability of such evidence. Objection has been made to admissibility in practically all of the cases in which use of such evidence has been attempted upon the ground that the evidence was hearsay and also that it was incompetent and irrelevant.

In all of the earhier cases in which survey evidence secured by modern sample survey techniques was presented, the courts either rejected the evidence as hearsay or failed to give it any weight in determining the issues involved. ${ }^{13}$ During the transitional period of 1920 to 1945 the legal scholars

1296 U.S. 245 (1878).

${ }^{13}$ See, e.g., John B. Stetson Co. v. Stephen L. Stetson Co., 14 F. Supp. 74 (S.D.N.Y. 1936), where the District Court for the Southern District of New York rejected such evidence as hearsay even though extensive and well designed tests were made. While occasionally such evidence has been admitted by a court, as in Lever Bros. Co. v. Butler Mfg. Co., 40 U.S.P.Q. 500 (Comm'r 1939), af'd, 27 C.C.P.A. (Patents) 1215, 111 F.2d 910, 45 U.S.P.Q. 580 (1940), over objection of opposing counsel, nevertheless the period from 1920 to 1945 was a transitional period where the evidence was more frequently refused admittance. However, this period was one where the courts discussed the nature of the evidence presented and recognized that, if admissible, it should be given weight upon the question of liklihood of confusion. Furthermore, where sample survey evidence was accepted, very little weight was given to the same because in most instances the surveys were not conducted in such a manner as to gain the confidence of the court as to the reliability of such evidence. 
who wrote on the subject of sample survey results were in agreement that this type of evidence should be recognized by the courts as being competent. All of those who wrote upon the subject did not agree as to the reason why the evidence was admissible. Some held that sample survey results were hearsay but should be admitted under an exception to the hearsay rule. Others maintained that such evidence was not hearsay and that, therefore, the hearsay rule did not apply and the sole question was the weight to be given such evidence.

The courts, recognizing the necessity of assistance in determining likelihood of confusion where evidence of actual confusion was not presented, have gradually come around to the view that survey evidence is admissible. The theory that the objection to survey evidence on the ground that it is hearsay is unfounded and that the question is one of the weight of the evidence was fully supported by Circuit Judge McLaughlin in Jacob Siegel Co. v. Federal Trade Commission. ${ }^{14}$

One of the leading cases upon the admissibility of survey evidence is United States v. 88 Cases, More or Less, Containing Bireley's Orange Beverage, ${ }^{15}$ wherein the Court of Appeals for the Third Circuit stated: "The hearsay objection is unfounded." The same court, in reversing the district court in Sears, Roebuck \& Co. v. Johnson, ${ }^{16}$ accepted a survey as competent evidence upon the question of the likelihood of confusion of the trade names there in question.

In the Ninth Circuit survey evidence was admitted by Judge McColloch sitting in the district court for Arizona in Household Finance Corp. $v$. Federal Finance Corp..$^{17}$ In admitting such evidence, Judge McColloch ruled specifically that such evidence did not violate the hearsay rule.

The use of the results of surveys upon the issue of likelihood of confusion has been recently approved in dictum by Chief Judge Leon Yankwich of the Southern District of California, in the case of Chun King Sales, Inc. v. Oriental Foods, Inc. ${ }^{18}$ Judge Yankwich went out of his way to approve the use of surveys inasmuch as no survey evidence was presented to the court in that case. In an earlier case, Sunbeam Corp. v. Sunbeam Lighting Co., Judge Yankwich had admitted the results of surveys in evidence

14150 F.2d 751 (3d Cir. 1944). See also S. C. Johnson \& Son, Inc. v. Gold Seal Co, 40 Trade-Mark Rep. 347 (1950), aff'd, 90 U.S.P.Q. 373, 41 Trade-Mark REp. 1024 (Comm'r 1951) where survey evidence was admitted in an opposition proceeding over objection that it was hearsay.

15187 F.2d 967 (3d Cir. 1951).

16219 F.2d 590 (3d Cir. 1955).

17105 F. Supp. 164 (D. Ariz. 1952).

18108 U.S.P.Q. 400, 403 (1956), citing Laskowitz v. Marie Designer, Inc., 119 F. Supp. 541 , 550 (S.D. Cal. 1954), and a relatively recent note on public opinion surveys as evidence in 66 HARV. L. REV. 498 (1953).

1983 F. Supp. 429 (S.D. Cal. 1949). 
and had used the same in determining the issue of likelihood of confusion. Although the decision in the Sunbeam case was modified by the Court of Appeals for the Ninth Circuit, ${ }^{20}$ the admissibility of such evidence was not disapproved by the court of review.

Survey evidence has even been used in an antitrust case as a means of reducing the volume of evidence and shortening the time of hearing. In United States v. United Shoe Machinery Corp., ${ }^{21}$ Judge Wyzanski suggested and encouraged the use of sample analyses and apparently the admissibility of such evidence was not questioned.

As a result of the admission of survey evidence upon the issue of likelihood of confusion in many recent cases and the approval of legal scholars, survey evidence is being more widely used than ever before, not only in trademark and unfair competition cases but in antitrust cases, ${ }^{22}$ telephone rate cases, ${ }^{23}$ Federal Trade Commission cases, ${ }^{24}$ and even in connection with the request for a change of venue in criminal cases. ${ }^{25}$

Although the decisions are not completely consistent upon the question of the admissibility of survey evidence, nevertheless the weight of opinion at the present time is that such evidence is admissible. We can, therefore, expect increasing use of this particnlar method of proving likelihood of confusion in trademark and unfair competition cases and will have reasonable assurance that the courts will accept the same as evidence provided that the survey is conducted in the proper manner.

What is the proper manner to conduct reaction tests will vary with the method used and the specific issues to be determined. The courts have admitted as evidence the results of sample surveys conducted by advertising agencies, ${ }^{28}$ by college professors, ${ }^{27}$ by psychologists, ${ }^{28}$ by direct mail advertising firms ${ }^{29}$ and by commercial research organizations. ${ }^{30}$

The sample surveys which have been conducted have been accomplished priniarily by personal interviews, teleplone calls and mail questionnaires.

20183 F.2d 969 (9th Cir. 1950).

21110 F. Supp. 295 (D. Mass. 1953), aff d, 347 U.S. 521 (1954).

22 See, e.g., United States v. E. I. Du Pont de Nemours \& Co., 118 F. Supp. 41 (D. Del. 1953).

${ }^{23}$ See, e.g., Tllinois Bell Tel. Co. v. Tlinois Commerce Comm'n, 414 Ill. 275, 111 N.E.2d 329 (1953).

24 See, e.g., Rhodes Pharmacal Co. v. Federal Trade Commission, 208 F.2d 382 (7th Cir. 1953), rev'd, 348 U.S. 940 (1955).

25 See, e.g., Irving v. State, 66 So.2d 288 (Fla. 1953).

26 Elgin National Watch Co. v. Elgin Clock Co., 26 F.2d 376 (D. Del. 1928).

27 Campbell Soup Co. v. Armour \& Co., 81 F. Supp. 114 (E.D.Pa. 1948), aff'd, 175 F.2d 795 (3d Cir. 1949).

28 People v. Franklin National Bank of Franklin Square, 200 Misc. 557, 105 N.Y.S.2d 81 (Sup. Ct. 1951).

20 Du Pont Cellophane Co. v. Waxed Products Co., 6 F. Supp. 859 (E.D.N.Y. 1934).

30 Laskowitz v. Marie Designer, Inc., 119 F. Supp. 541 (S.D. Cal. 1954). 
The courts have not specified how sample surveys should be conducted or who should conduct them. However, the decisions indicate the necessity of conducting the test in such a manner as to enable the courts to utilize and to give weight to the results.

The necessity of securing results which would be acceptable to the courts would seem to be met where the test or survey was conducted under the supervision of experts. Fortunately there are organizations in existence which are fully qualified to give this service. These experts can assume responsiblity for the training of the personnel to conduct interviews. They are able to assist in formulating the questions to be asked or in choosing the Inaterial to be used in conducting the survey and are available to prepare results of the test and help in analyzing the same. Furthermore, they are available for use at the trial as witnesses and can testify not only as to what was done but, as experts, are useful in interpreting the results.

The choice of material to be used in surveys would depend upon the objective to be accomplished. The market conditions under which the product under investigation is sold should be approximated as closely as possible and an attempt should be made to obtain the same reaction that would be obtained if the tests were made in the market place.

The selection of the geographic area in which the survey is to be made is determined to a large extent by the nature of the product and the territory within which the product is sold and is known. Whether a house to house survey should be made also depends upon the nature of the product or products involved. In some instances interviewers would be limited to certain types or business establishments, such as garages and service stations. In other instances, they might be himited to doctors, dentists or druggists. The himitations would depend upon who had knowledge of the specific use of the mark or goods in question.

The tests should be sufficiently broad in scope to be statistically reliable, and the number of persons interviewed should represent a sufficiently large segment of the purchasing public to lend general significance to the results. An example of the failure of those conducting the survey to appreciate the proper segment of the purchasing public to be interviewed was clearly demonstrated in Lerner Stores Corp. v. Lerner, ${ }^{31}$ a case involving confusion between the trade names of the litigants. Surveys were made in San Francisco to establish likelihood of confusion in San Jose. The result was that the Court of Appeals for the Ninth Circuit paid little or no attention to the results of the tests. If the tests had been conducted in San Jose, reactions secured would undoubtedly have been given more weight.

All tests should be designed so that they are free from attack on the

31162 F.2d 160 (9th Cir. 1947). 
ground that they bias or "trigger" any particular response. In formulating questions, the ultimate use to be made of the survey and its results should always be kept in mind. Leading and trick questions should be avoided. Inasmuch as the persons interviewed have no particular knowledge or interest in the issues involved, the questions should be as short as possible and the number of the same should be limited. Obviously a busy housewife or a storekeeper will be more apt to cooperate in answering relatively brief questions, both in length and number, than they would if the questions were lengthy or involved.

In order to be admissible or to have any probative value, a test or survey may comprise nothing of an "opinion poll" character. It must be a cumulation of reactions, but never opinions as to what reactions might be. It is fully appreciated that it is difficult to formulate questions which will not elicit an opinion response. The assistance of experts who have had considerable experience in formulating and conducting tests is often invaluable to avoid the securing of opinion evidence.

Upon completing the surveys the interviewers should make full reports, setting forth in detail the facts of the conduct of the survey and probably should be required to make affidavits. All persons who have anything whatsoever to do with the design and conduct of a reaction test should be called as witnesses and should testify regarding the manner in which the survey was conducted and the material used. The basic evidence, of course, is the interview sheets or material which their testimony would merely authenticate.

When the interview is conducted, those interviewed may well be asked if they would testify at the trial. Some suggestions have been made that all public witnesses should be subpoenaed so that they would be available for cross-examination and so that the objection of hearsay testimony could be answered. However, many persons are actually afraid of testifying in court; others have not sufficient interest to take the necessary time. However, if discretion is used, sufficient witnesses should be produced in court to enable the court to determine the overall credibility of the survey and the rehance that should be placed upon it.

No survey or reaction test of any kind is conclusive proof on the question of likelihood of confusion. The reason is that it is virtually impossible to sinulate perfectly the conditions of the trade and particularly the conditions which exist in the market place. For this reason some authors show a preference for surveys which are made in the trade over surveys which are made froin house to house.

The importance of conducting a test properly so that it will receive consideration by the court upon the question of likelihood of confusion is given emphasis by the decision of the Commissioner of Patents in S.C. 
Johnson \& Son, Inc. v. Gold Seal $\mathrm{Co}^{32}$ Although the survey made was admitted in evidence, the Commissioner severely criticized the questionnaire, stating that the questions and the questionnaire were biased. Because of this, no weight was given to the evidence presented. We cannot overemphasize the importance of properly conducting any survey made. If properly made, the present tendency of the courts is to admit it in evidence and to give it consideration upon the question of likelihood of confusion. 


\section{California Law Review}

MLEMIBER NATIONAL AND WESTERN CONEERENCES OF LAW REVIEWS

Published Five Times Yearly by Students of the School of Law of the

University of California, Berkeley, California. Indexed in Index to Legal Periodicals and Public Affairs Information Service.

Subscription Price, $\$ 5.00 \quad$ Current Single Copies, $\$ 1.50$

\section{BOARD OF EDITORS}

CFARLES W. FroEHEICH JR. Editor

\section{H. HetMut Loring \\ Assistant Editor}

E. Llewellys Overholt Jr.

Managing Editor

MARTLN J. Rosen

Article Editor

ROBERT W. MACMAHON

Revising Editors

Patd Adirs Peterson

Ciayton P. Roche

JERRY J. PHELAN

ROBERT G. STELIER

Donatd K. BJELKe

Associate Editors

ROBERT I. CONN

David L. Noracast

PETER STMMONS

ROBERT I. CONN

Special Article Editor for Trademark Symposium

Marityn MTtchetr

General Secretary

WIILTAMT R. BERKMAN

Donald M. Camen

Michaed G. HaRrington

BILLY H. HuNT

Donald L. Knvg

JAMTES F. KIRRHAM

Gerald R. KNECHT

Marshatl W. KraUSE

Richard T. LEMMMON

RodNex J. LINDQUIST JR.

JoHN D. MCFEeters JR.
Contributors

Marc H. MonhenIer

Robert O. NagLe

SterLING OsMoN

Wartace R. Peck

Eugene E. Reynolds JR.

Robert A. Setigson

JoEn E. SPARKs

JoHn F. TAYLOR

LEwIS L. VoHLAND

StantoN G. WARE

LAVERNE J. WOLFE 